This paper is published as:

Hantziagelis, S, McCabe, BY, 2006, "Benchmarking airport reconstruction projects", Canadian Journal of Civil Engineering, 33 (12):1571-1584 doi: 10.1139/L05-095

\title{
BENCHMARKING AIRPORT RECONSTRUCTION PROJECTS
}

\author{
Sandra Hantziagelis \\ Master of Applied Science \\ Department of Civil Engineering, \\ University of Toronto, Toronto, ON
}

\author{
Brenda McCabe \\ Associate Professor \\ Department of Civil Engineering, \\ University of Toronto, Toronto, ON \\ mccabeb@civ.utoronto.ca \\ ph 416-946-3505
}

\begin{abstract}
The impact of redevelopment and expansion of airport operations has not received much attention in the literature. Data were collected for 22 North American airports, 26 airport projects, and 107 individual operational years (airport-years) with at least 3.5 million passengers annually, each of which under took a brownfield passenger terminal project between 1991 and 2001. The results indicate that some factors may be indicative of airport redevelopment impacts, such as traffic volume, cargo, and air traffic movements. It was also found that the strategic use of space is critical to operational efficiency, especially with the full range of non-aeronautical services that can be offered at airports. The cost of space may be higher, but it tended to improve overall efficiency. Reconstruction projects that were evaluated as successful tended to show operational recovery within 2 years of completing construction; this result was consistent through a wide range of project sizes, traffic levels, and services.
\end{abstract}

KEYWORDS: Airport terminal reconstruction, benchmarking, reconstruction impacts, airport performance measures, data envelopment analysis (DEA)

\section{INTRODUCTION}

As with all forms of public infrastructure, airports are closely tied to the region they serve and significant resources are needed for their development and maintenance. Approaching the end of the $20^{\text {th }}$ century, the air travel system around the world was congested, and most airports were undergoing redevelopment and/or expansion programs to increase their capacity.

The impacts of redevelopment and expansion of airports and their operations have not received much attention in the literature to date, despite the high activity. A number of negative impacts can arise both during the project and after its completion due to the surge of capacity, high capital costs, interference by and to existing operations, and underutilization of facilities. Although these conditions existed before September 2001, recent international security problems have magnified their influence. Therefore, there is a need to understand and control these impacts. 
A recent University of Toronto study investigated the effects that expansion has on airport performance. The study focussed on North American airports using data envelopment analysis (DEA) to benchmark operational performance before and after construction. The results were examined to both identify and quantify the impacts of the capital projects on the respective airport's performance and efficiency over time, and if specific factors may be used as indicators of short terms impacts. The ability to understand the impacts and how they may be mitigated is a tool of a great value to owners, managers and other stakeholders in the airport industry.

\section{BACKGROUND}

During the surge of airport redevelopment and expansion, airport management philosophies were also changing. In the past 2 decades, airports have moved from being public assets (owned and operated) to private enterprises. As such, commercial practices and standards were adopted, and performance benchmarking was introduced (Doganis 1992; Francis et al. 2002).

Benchmarking is a process of comparing the performance of an enterprise, measured in several ways, with that of the best in the industry (de Neufville and Guzman 1998). A general approach to benchmarking a group of organizations is (Graham 2003):

- Identify areas of the operation to benchmark

- Identify measures that reflect the area of operation

- Identify the set of firms to be compared - they must operate in a similar environment

- Analyze airport performance and examine the differences

- Identify strategies to improve performance by examination of the results

- Implement improvement strategies and assess the results

This approach is referred to as external benchmarking. In contrast, internal benchmarking looks at the performance of a business unit over time. Although consistent data are easier to collect in this manner, internal benchmarking cannot compare performance to what has been achieved by others (Doganis 1992; Graham 2001; Graham 2003). External benchmarking can justify to owners, managers, clients, investors, and regulators the initial costs of changes and improvements. For example, the Federal Aviation Authority (FAA) uses benchmarking to help prioritize financial assistance amongst its airports. The difficulties of external benchmarking are the lack of standards for data reporting, poor sharing of information across airports, and the uniqueness of airports. To increase comparability and add value to study results, these difficulties can be minimised by the careful selection of the firms to be benchmarked and increased data quality.

Generally, there are two types of benchmarking used for airports: parametric and non-parametric. Parametric techniques include regression analyses and stochastic frontier analysis (SFA). These techniques require a large amount of data to determine the theoretical standard or benchmark frontier (Hooper and Hensher 1997; ATRS 2002). Common non-parametric techniques include total factor productivity (TFP) and data envelopment analysis (DEA) (Gillen and Lall 1997; Cooper and Gillen 1994; Sarkis 2000; Pels et al. 2001; Martín and Roman 2001; Fernandes and Pacheco 2002). Both TFP and DEA produce empirical benchmarks using indexed inputs and outputs, and are less demanding on the quantity and complexity of the data required. All of these techniques are based on developing models of operational inputs and outputs. Table 1 outlines a number of common inputs and outputs of airport operations.

Table 1: Common input variables for performance

\begin{tabular}{lll}
\hline Performance & Inputs & Outputs \\
\hline Financial & - Assets & - Revenue (total, aeronautical, commercial) \\
& - Costs (total, operating, labour, capital, & - Profit \\
\hline
\end{tabular}




\begin{tabular}{llll}
\hline & maintenance) & - Return on investment & \\
\hline Physical & - Fixed Assets (runways, terminal & - Passengers & - Cargo \\
& space, parking garages, check in desks, & - Work load units (WLU) & - Service levels \\
& gates, aprons, taxiways, hangars) & - Energy consumption & - Noise \\
& & - Air traffic movements (ATM) \\
\hline
\end{tabular}

Physical capital inputs are assets, such as runways, terminal space, or hangars. Financial capital inputs are total costs, operating costs, capital costs, and maintenance costs. Costs are often influenced by external variables, such as labour, energy, and local market conditions (NERA 2001). If costs are to be included, disaggregating costs and examining income statements can help increase comparability in costs figures (Cooper et al. 1994).

Labour and labour costs are important inputs in both physical and financial form, but their quantification can be difficult due to differences in the management practices and local market conditions (NERA 2001). It is difficult to obtain consistent measures of labour as it can be represented as hours worked or hours paid (Hooper et al. 1997; Doganis et al. 1987).

In addition to common financial outputs of revenue or profit, outputs for airports usually refer to flows such as passengers, cargo, and air traffic movements (ATMs). Financial output measures (such as revenues and returns on investment) are important for performance analysis, but as they define the bottom line for most businesses, it has been well established that financial measures do not capture efficiency of operations nor do they reflect the overall purpose of the airport (Doganis and Graham 1987).

Of the physical outputs, passengers tend to be the most significant. Annual passenger count and composition influence operation costs, revenue, and the design of physical spaces. Cargo counts include freight and mail and are usually secondary to passengers with the exception of cargo hub airports. The cargo activities are important because they can raise costs but do not contribute to revenues to the same extent as passengers (NERA 2001). The work load unit (WLU) combines passenger and cargo activity by equating one passenger ( $80 \mathrm{~kg}$ person $+20 \mathrm{~kg}$ baggage) with $100 \mathrm{~kg}$ of cargo (Doganis and Graham 1987). WLU is often criticised because it does not adequately reflect the different costs and revenues associated with passengers and cargo (Graham 2001; 2003; Humphreys and Francis 2000; Doganis 1992).

Air traffic movements (ATM) measure airside operations, but it does not take into account the size of facilities or aircraft (Mackenzie-Williams 1997). Locations with larger aircraft usually realise higher passenger volume and revenues.

As there are no industry-accepted standards for airport performance measures, there is much controversy over any current or proposed measure. There are about 20 measures in common use (Graham 2001; 2003), and most are economic measures. Table 2 lists common categories (Graham 2001; Graham 2003; Doganis 1992; Hooper and Hensher 1997; NERA 2001).

Table 2: Common airport performance measures

\begin{tabular}{|c|c|c|c|}
\hline Category & Measures & Category & Measures \\
\hline $\begin{array}{l}\text { Capital } \\
\text { Productivity }\end{array}$ & $\begin{array}{l}\text { - } \quad \text { WLU/Total Assets } \\
\text { - } \quad \text { Revenue/Total Assets } \\
\text { - } \quad \text { Total Assets/Employee } \\
\text { - } \quad \text { ATMo/Total Assets } \\
\text { - }\end{array}$ & $\begin{array}{l}\text { Revenue } \\
\text { Generation }\end{array}$ & $\begin{array}{l}\text { - } \quad \text { Total revenue/WLU } \\
\text { - } \quad \text { Commercial revenue/WLU } \\
\text { - } \quad \text { Aeronautical revenue/WLU } \\
\text { Total Renautical revenue as \% of } \\
\text { - Total Revenue/1000 Net Asset } \\
\text { Value }\end{array}$ \\
\hline
\end{tabular}




\begin{tabular}{|c|c|c|c|}
\hline Category & Measures & Category & Measures \\
\hline $\begin{array}{l}\text { Labour } \\
\text { Productivity }\end{array}$ & $\begin{array}{l}\text { - WLU/Employee } \\
\text { - } \quad \text { Total Revenue/Employee } \\
\text { - Value Added/Employee } \\
\text { Capital Costs } \\
\text { - Value Added /Unit Staff } \\
\text { Costs }\end{array}$ & $\begin{array}{l}\text { Commercial } \\
\text { Performance }\end{array}$ & $\begin{array}{l}\text { - Concession + Rental Income } \\
\text { /Passenger } \\
\text { - Concession Revenue /Passenger } \\
\text { - Rent or Lease Income } \\
\text { /Passenger } \\
\text { - Concession Revenue } / \mathrm{m}^{2}\end{array}$ \\
\hline $\begin{array}{l}\text { Cost } \\
\text { Efficiency/ } \\
\text { Overall Cost } \\
\text { Performance }\end{array}$ & $\begin{array}{l}\text { - } \quad \text { Total Cost (including } \\
\text { depreciation \& interest) } / \text { WLU } \\
\text { - Total Cost (excluding } \\
\text { depreciation) } / \text { WLU } \\
\text { - } \quad \text { Total Cost (including } \\
\text { depreciation) } / \text { WLU } \\
\text { - Operating Cost (including } \\
\text { depreciation \& interest) } / \text { WLU } \\
\text { - } \quad \text { Capital Cost/WLU } \\
\text { - } \quad \text { Labour Cost/WLU } \\
\text { - } \quad \text { Aeronautical Cost/WLU } \\
\text { - } \quad \text { Depreciation Cost/WLU } \\
\text { - } \quad \text { Labour Cost/Total Cost } \\
\text { - } \quad \text { Capital Cost/Total Cost }\end{array}$ & $\begin{array}{l}\text { Profit } \\
\text { Generation }\end{array}$ & $\begin{array}{l}\text { : } \text { Surplus/WLU } \\
\text { Deficit/WLU } \\
\text { \& tax) / WLU } \\
\text { : Operating Profit ( } \pm \text { depreciation) } \\
\text { /Total Assets } \\
\text { Operating Profit ( } \pm \text { depreciation) } \\
\text { MLU } \\
\text { (REVEX) }\end{array}$ \\
\hline
\end{tabular}

Productivity measures address operational outputs given the inputs, and provide insight to whether operations are efficient (Cooper and Gillen 1994). Capital productivity examines physical assets and their ability to generate revenues. Because they indicate the strength of assets to produce revenue, they are used by owners and managers to attract investors (Doganis 1992). Concerns exist due to their dependence on accounting policies on valuing assets and that they have little relevance to resource use (Hooper and Hensher 1997).

Labour productivity differentiates outsourcing trends across locations. For example, full time equivalents might not include labour supplied by contracted firms. Some measures may have greater significance where labour is a large component of the operation, such as large scale handling activities in European airports (Doganis 1992).

Usually, revenue and profit measures assess the efficiency of a business; however, many airports are non-profit organisations (Cooper and Gillen 1994). Thus, profit may be misleading and not reflective of operation efficiency (Gillen and Lall 1997; NERA 2001). Enterprises can be inefficient and yet produce high profits, while low profit firms can be highly productive due to competition (Hooper and Hensher 1997; Martín and Roman 2001).

Capital productivity measures, such as return on assets, can be an alternative to profit and revenue. REVEX (revenue to expenditure ratio) has been used with airlines to see if costs are recovered (Doganis 1992). Commercial performance is a new area in airports business and can often be a significant contributor to overall performance and operations. There are several measures that address the commercial performance of an airport, often to observe the contribution between the aeronautical and commercial activities.

The final group of measures address cost performance, often in unit costs, and are regarded as overall measures of operational efficiency. Such measures are often in annual reports showing changes in operational efficiency over time, or their relation to other airports. These measures are highly aggregated to reflect the entire airport and are those often used for comparative purposes. 


\section{DATA ENVELOPMENT ANALYSIS}

Data envelopment analysis (DEA) has been used to analyze airport performance (Cooper and Gillen 1994; Gillen and Lall 1997; Martín and Roman 1997; Sarkis 2000, Alder and Berechman 2001; Pels et al. 2001; Fernandes and Pacheco 2002; Bazargan and Vasigh 2003). The popularity of DEA arises in its ease of use and the results it produces. It aims to quantify efficiency, a ratio of output to input, and guide improvement by suggesting changes to specific inputs and outputs.

DEA is a non-parametric linear programming technique that produces an empirical efficiency score. The process involves the creation of a piecewise efficiency frontier defined by the best performers or decision-making units (DMUs). Efficiency scores other than 1.0 are calculated for the remaining inefficient firms in relation to the frontier. A schematic representation is presented in Figure 1.

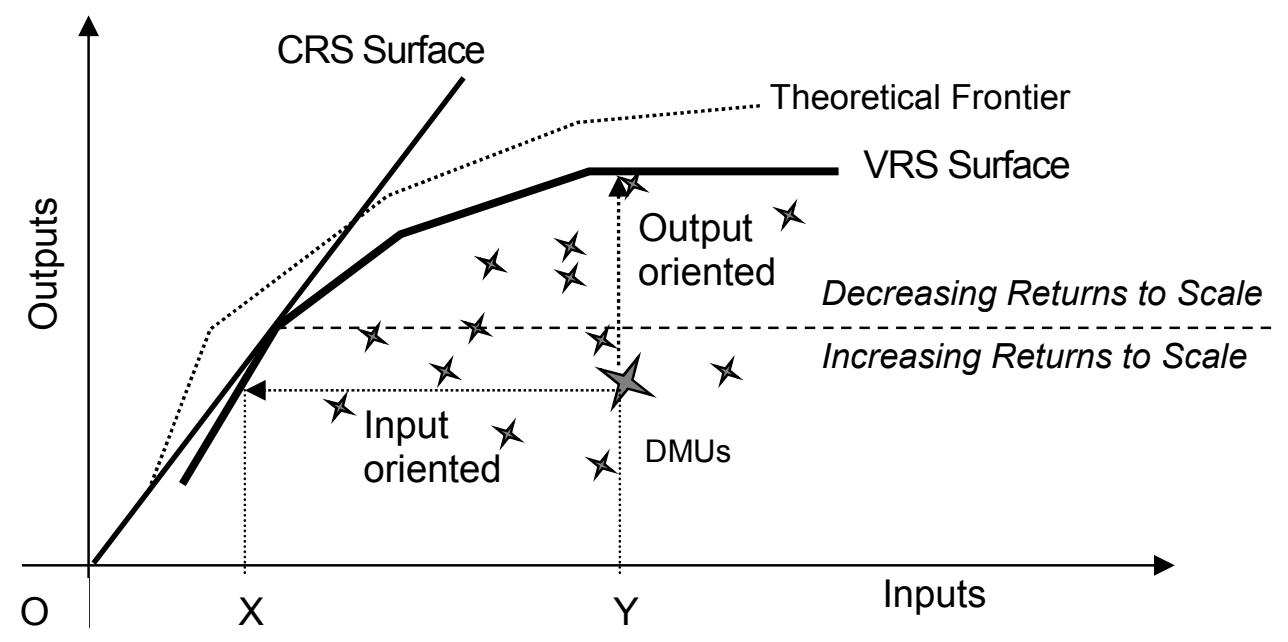

Figure 1: DEA Frontiers - 2D Example

DEA results guide individual firms to improve their efficiency according to their position in relation to the frontier and the efficient peer DMUs. The peer count is the number of inefficient DMUs that use an efficient DMU as a guide for improvement. Efficient DMUs with a peer count of 0 are labelled outliers. To ensure model strength, the sample should be a minimum of three times the sum of the number of input and output variables, and results should not be skewed by a high number of outliers (Banker et al. 1984).

There are two main DEA models, defined by their frontier surface. Charnes, Cooper and Rhodes (1978) first developed the CCR model with constant returns to scale (CRS) surface. This frontier starts at the origin and is lowered until it meets a DMU. Later, Banker (1984), Charnes and Cooper developed the BCC model with a variable returns to scale (VRS) surface, which is increasing returns to scale (IRS) below the intersection with the CRS line, or decreasing returns to scale (DRS) above it (refer to Figure 1). The selection is often determined by the nature of the operations or firms to be analysed. The model is further defined and examined as either an input or output oriented model. In an output oriented model, the input variables are fixed and efficiency is based upon maximizing the outputs. Conversely, output variables are fixed and input variables are minimized in an input oriented model. If the DMU in Figure 1 were compared using input-oriented analysis, its efficiency would be based on holding the output steady, and extending a line to the frontier to determine how its peers manage to produce the same output with fewer inputs. In the two dimensional case, the efficiency of that DMU would be X/Y. DEA models in multiple dimensions are solved using linear programming. Equation 1 presents the formulation in a fractional linear format. 


$$
\begin{array}{ll}
\max \mathrm{h}_{\mathrm{o}}=\frac{\sum_{r=1}^{t} u_{r} y_{r j o}}{\sum_{i=1}^{m} v_{i} x_{i j o}} & \\
\text { subject to } \frac{\sum_{r=1}^{t} u_{r} y_{r j}}{\sum_{i=1}^{m} v_{i} x_{i j}} \leq 1, \mathrm{j}=1, \ldots, \mathrm{n}, & \mathrm{u}_{\mathrm{r}}, v_{i}=\varepsilon \\
& \multicolumn{1}{c}{\text { where } \mathrm{h}_{\mathrm{o}}=\text { efficiency measure }} \\
\mathrm{y}_{\mathrm{rj}}=\text { output } \mathrm{r} \text { from unit } \mathrm{j} & \mathrm{n}=\text { number of units } \\
\mathrm{x}_{\mathrm{ij}}=\text { input } \mathrm{i} \text { from unit } \mathrm{j} & \mathrm{t}=\text { number of outputs } \\
\mathrm{u}_{\mathrm{r}}=\text { weight of output } \mathrm{r} & \mathrm{m}=\text { number of inputs } \\
\mathrm{v}_{\mathrm{i}}=\text { weight of input } \mathrm{i} & \varepsilon=\text { small positive number }
\end{array}
$$

Equation 1 depicts the ratio as a weighted sum of outputs to the weighted sum of inputs. The linear programming form presented in Equation 2 shows outputs as a numerator and inputs as the denominator.

$$
\begin{aligned}
\max \text { ho }= & \sum_{r=1}^{k} u_{r} y_{r j o} \\
\text { subject to } & \sum_{i=1}^{m} v_{i} x_{r j o}=100 \\
& \sum_{r=1}^{k} u_{r} y_{r j o}-\sum_{i=1}^{m} v_{i} x_{r j o}=100 \\
& j=1, \ldots, n \\
& -u_{r} \leq-\varepsilon, r=1, \ldots k \\
& -v_{i} \leq-\varepsilon, i=1, \ldots m
\end{aligned}
$$

Two data adjustments commonly used in DEA are translation and scaling. Scale invariance in both BCC and CCR models means that inputs or outputs can be scaled without affecting efficiency scores. For example, distance values may be expressed as inches, kilometres, or light years without affecting the results. Translation invariance allows for scalar translation of input or outputs, but only applies to translation of inputs in an output oriented BCC, and of outputs in an input oriented BCC. CCR models are not translation invariant. This is very important, as DEA is unable to handle negative variables, and translation (the addition of a scalar) may be required to eliminate negatives.

\section{DATA COLLECTION}

The airports chosen for this research operated at a minimum of 3.5 million passengers annually to ensure minimal influence of economies of scale (Graham 2001; Graham 2003; Doganis 1992). The eligible projects were passenger terminal expansion or new terminal construction that resulted in new space and/or gates (replacing a roof did not qualify). Construction must have begun by 1991 and completed by 2001, allowing for a minimum of 1 year of post project operation. The projects also needed a degree of isolation with respect to time and cost from other projects so that its parameters may be established.

Data collection was a lengthy and iterative process that resulted in data for 22 airports, 26 airport projects, and 107 individual operational years (airport-years). The high response rate of $72.4 \%$ was due to continual follow up with the contacts at the airport authorities.

The data represented commonly published airport inputs and outputs, and was taken in two groups data for yearly operations and those pertaining to the project. Operations data were collected for a minimum of 4 years for each project: prior to construction (year 1), construction commencement (year 
2), construction completion (year 3), and one or two years post completion (years 4 and 5). The data, shown in Table 3, were collected from many resources including annual reports, traffic reports, databases, balance sheets, and customized surveys sent to each airport.

With the exception of general information, data were collected for each year. Definitions were established to ensure consistency. For example, gates were measured as equivalent gates, where 2 commuter gates are equivalent to 1 bridged gate. Definitions generally followed Airports Council International (ACI 1998; 2003) for traffic figures and the FAA's Compliance Activity Tracking System (CATS) for financial information. Difficulties were experienced in the collection of physical inventory and for data prior to the mid-1990s. This was similar to discussions found in the literature that suggested the difficulty was due to the lack of standards in reporting and generally poor sharing of information in the industry (de Neufville and Guzman 1998).

Table 3: Data collected

\begin{tabular}{|c|c|c|}
\hline Data Category & Details & \\
\hline General & $\begin{array}{l}\text { - } \text { Airport name, location and code } \\
\text { - Originating-destination or hub }\end{array}$ & - International gateway \\
\hline Traffic & $\begin{array}{l}\text { - Annual passengers } \\
\text { - Annual cargo (tonnes) }\end{array}$ & - Annual ATMs \\
\hline Physical inventory & $\begin{array}{l}\text { - Total airport passenger terminal area }\left(\mathrm{m}^{2}\right) \\
\text { - Total airport gates (equivalents) }\end{array}$ & $\begin{array}{l}\text { - Total airport runways (end } \\
\text { counts) }\end{array}$ \\
\hline Financial & $\begin{array}{ll} & \text { Total assets } \\
\text { - } & \text { Total debt } \\
\text { - } & \text { Total revenue }\end{array}$ & $\begin{array}{l}\text { - } \text { Operating revenue } \\
\text { - } \quad \text { Total cost } \\
\text { - } \text { Operating cost }\end{array}$ \\
\hline Project specifics & $\begin{array}{ll}\text { - } & \text { Description } \\
\text { - } & \text { Cost } \\
\text { - } & \text { Construction period }\end{array}$ & $\begin{array}{ll}\text { - } & \text { Space built }\left(\mathrm{m}^{2}\right) \\
\text { - } & \text { Gates built (equivalents) }\end{array}$ \\
\hline
\end{tabular}

The airports and their projects included in this study are outlined in Table 4. With the exception of BWI, $\mathrm{PHL}$, and SLC, one project was included in the analysis for each airport. In some cases (BWI, MEM, MSY, MSP, and SLC), a project represented several smaller projects, but due to schedule overlaps and project scale, these projects were combined. For SLC and BWI, an additional project was made by combining 2 projects to observe any difference between having projects separated or combined. The project information collected for each project is summarized in the Table 5, evidence of the great range of project sizes included in the analysis.

Table 4: Airport projects

\begin{tabular}{cllll}
\hline \multicolumn{1}{c}{ Airport } & Project & Constr'n & Data Years \\
\hline ATL & $\begin{array}{l}\text { Hartsfield Atlanta } \\
\text { International }\end{array}$ & Concourse E & $1991-1994$ & $1990,1991,1994,1995,1996$ \\
BWI & $\begin{array}{l}\text { Baltimore/ Washington } \\
\text { International }\end{array}$ & $\begin{array}{l}\text { Pier C Extension } \\
\text { New International } \\
\text { Terminal }\end{array}$ & $\begin{array}{l}1994-1996 \\
1994-1997\end{array}$ & $1995^{\star}, 1996,1997,1998,1999$ \\
CLE & $\begin{array}{l}\text { Cleveland Hopkins } \\
\text { International }\end{array}$ & New Terminal D & $1997-1999$ & $1996,1997,1999,2000,2001$ \\
CMH & $\begin{array}{l}\text { Port Columbus } \\
\text { International }\end{array}$ & North Concourse Project & $1994-1995$ & $1993,1994,1995,1996,1997$ \\
\hline
\end{tabular}




\begin{tabular}{|c|c|c|c|c|}
\hline & Airport & Project & Constr'n & Data Years \\
\hline \multirow[t]{4}{*}{ CVG } & Cincinnati/Northern & New Terminal 3 & 1991-1994 & $1990,1991,1994,1995,1996$ \\
\hline & Kentucky International & Concourse A Extension & 1991-1994 & \\
\hline & & New Concourse C & 1991-1994 & \\
\hline & & New Concourse B & 1991-1994 & \\
\hline FLL & $\begin{array}{l}\text { Fort Lauderdale/ } \\
\text { Hollywood International }\end{array}$ & $\begin{array}{l}\text { New Concourse C/ } \\
\text { Terminal } 1\end{array}$ & $1999-2001$ & 1998,1999,2001, 2002 \\
\hline LAS & $\begin{array}{l}\text { McCarran International, } \\
\text { Las Vegas }\end{array}$ & Satellite D Project & 1996-1998 & $1995,1996,1998,1999,2000$ \\
\hline MCO & Orlando International & $\begin{array}{l}\text { New } 4^{\text {th }} \text { Airside Terminal } \\
\text { (Airside } 2 \text { ) }\end{array}$ & $1998-2000$ & $1997,1998,2000,2001,2002$ \\
\hline MEM & Memphis International & $\begin{array}{l}\text { Terminal B-C Connection } \\
\text { \& Terminal C Renovation }\end{array}$ & $2000-2001$ & $1999,2000,2001,2002$ \\
\hline \multirow[t]{2}{*}{ MSP } & $\begin{array}{l}\text { Minneapolis/ St.Paul } \\
\text { International }\end{array}$ & $\begin{array}{l}\text { Lindbergh Terminal } \\
\text { Expansion - Phase } 1\end{array}$ & $1998-2001$ & $1997,1998,2001,2002$ \\
\hline & & New Humphrey Terminal & $1999-2001$ & \\
\hline \multirow[t]{2}{*}{ MSY } & New Orleans International & Concourse C Addition & 1994-1996 & $1992,1993,1996,1997,1998$ \\
\hline & & West Terminal Expansion & 1993-1995 & \\
\hline PDX & Portland International & Terminal Expansion South & $1997-1998$ & $1996,1997,1998,1999,2000$ \\
\hline $\mathrm{PHL}$ & Philadelphia International & $\begin{array}{l}\text { Terminal B/C Consol'n } \\
\text { Terminal F }\end{array}$ & $\begin{array}{l}1995-1998 \\
1999-2001\end{array}$ & $\begin{array}{l}\text { 1994,1995,1998, } \\
1999,2000,2001,2002\end{array}$ \\
\hline SEA & $\begin{array}{l}\text { Seattle Tacoma } \\
\text { International }\end{array}$ & Concourse D Expansion & 1994-1995 & $1990,1991,1992,1993,1994$ \\
\hline SFM & Sacramento International & New Terminal A & $1996-1998$ & $1998,1996,1997,1999,2000$ \\
\hline SFO & $\begin{array}{l}\text { San Francisco } \\
\text { International }\end{array}$ & $\begin{array}{l}\text { New International } \\
\text { Terminal }\end{array}$ & $1996-2000$ & $1995,1996,2000,2001,2002$ \\
\hline SLC & $\begin{array}{l}\text { Salt Lake City } \\
\text { International }\end{array}$ & $\begin{array}{l}\text { Terminal } 2 \text { East } \\
\text { Expansion } \\
\text { International Terminal }\end{array}$ & $\begin{array}{l}1992-1995 \\
1994-1995\end{array}$ & $\begin{array}{l}\text { 1991,1992,1993, } \\
1994,1995,1996,1997\end{array}$ \\
\hline TPA & Tampa International & Airside A & 1993-1995 & $1992,1993,1995,1996,1997$ \\
\hline YEG & Edmonton International & SE Terminal Expansion & $1999-2000$ & 1998,1999,2001, 2002 \\
\hline YVR & Vancouver International & $\begin{array}{l}\text { New International } \\
\text { Terminal }\end{array}$ & 1993-1996 & $1992,1993,1996,1997,1998$ \\
\hline YYC & Calgary International & Concourse A Expansion & $1998-2000$ & $1997,1998,2000,2001,2002$ \\
\hline YYZ & $\begin{array}{l}\text { Toronto Pearson } \\
\text { International }\end{array}$ & New Terminal 1 & $\begin{array}{l}\text { 1998- In } \\
\text { Progress }\end{array}$ & 1997,1998 \\
\hline
\end{tabular}

\section{MODEL DEVELOPMENT}

To identify influencing factors and indicators of the impacts of development on performance, three analyses were undertaken: general, project, and overall. In the general analysis, DEA was used to obtain measures of efficiency for each airport-year and these results were correlated to identify factors that may be indicative of successful programs. In the project analysis, changes in efficiency over the duration of the projects were correlated with factors and performance measures. Third, an overall DEA analysis was undertaken to examine the efficiency of the 26 projects; these results were correlated, and compared to the yearly DEA efficiency results. All models were developed to meet accepted guidelines for DEA models to avoid separation of DMUs. This was done by ensuring that the number of DMUs for each model was at least three times the sum of inputs plus outputs, or the minimum of the product of the number of inputs and the number of outputs (Boussofiane et al. 1991). The larger the multiple, the more robust the model - this was taken into account when developing the models. 


\section{General Models}

The models were input oriented BCC models. The variable returns to scale surface accommodates the various sized airports in the sample. Input orientation was selected to analyse the effect of the project products (space and gates) that may have been reduced to improve efficiency. The models developed are outlined in With the project models, a total of 5 inputs plus outputs were allowed given the sample of 26 projects. Project Model 1 examined the efficiency of output changes given the change in capacity. Project Model 2 examined the efficiency of change in output given the unit costs for the space and gates.

Table 6 . Models 1 and 2 were configured by incorporating single absolute measures for input and output, and differ by the incorporation of assets as input. General Model 3 was developed with performance ratios.

Table 5: Project information

\begin{tabular}{|c|c|c|c|}
\hline Airport & \$CAN 2002 (millions) & Space $\left(m^{2}\right)$ & Gates Built \\
\hline ATL & 435.6 & 155,446 & 24 \\
\hline BWI1 & 41.1 & 11,148 & 6 \\
\hline BWI2 & 188.2 & 27,870 & 3 \\
\hline BWI3 & 229.2 & 39,018 & 9 \\
\hline CLE & 181.4 & 10,793 & 25 \\
\hline $\mathrm{CMH}$ & 32.6 & 13,195 & 4 \\
\hline CVG & 641.7 & 119,639 & 59 \\
\hline FLL & 141.5 & 41,433 & 9 \\
\hline LAS & 455.4 & 70,277 & 26 \\
\hline $\mathrm{MCO}$ & 162.2 & 29,542 & 16 \\
\hline MEM & 28.2 & 3,967 & 17 \\
\hline MSP & 175.0 & 88,911 & 36 \\
\hline MSY & 35.4 & 23,852 & 15 \\
\hline PDX2 & 77.0 & 11,148 & 13 \\
\hline PHL1 & 178.2 & 7,060 & 0 \\
\hline PHL2 & 122.4 & 17,186 & 38 \\
\hline SEA & 122.0 & 29,542 & 6 \\
\hline SFM & 77.3 & 25,547 & $16(10)^{*}$ \\
\hline SFO & $1,371.9$ & 232,250 & $24(21)^{*}$ \\
\hline SLC1 & 7.8 & 2,570 & 17 \\
\hline SLC2 & 113.3 & 15,459 & 13 \\
\hline SLC3 & 121.1 & 18,029 & 30 \\
\hline TPA & 155.8 & 21,832 & 14 \\
\hline YEG & 78.0 & 2,229 & $11(2)^{*}$ \\
\hline YVR & 280.0 & 92,900 & 16 \\
\hline YYC & 28.9 & 16,300 & 4 \\
\hline
\end{tabular}




\section{Project Models}

The two project models were developed to look at the efficiency of the project, costs and products, to the change in output over the period, as outlined in Table 7.

With the project models, a total of 5 inputs plus outputs were allowed given the sample of 26 projects. Project Model 1 examined the efficiency of output changes given the change in capacity. Project Model 2 examined the efficiency of change in output given the unit costs for the space and gates.

Table 6: General models

\begin{tabular}{|c|ll|ll|c|}
\hline Model & Inputs & Outputs & DEA Multiple \\
\hline 1 & $\begin{array}{l}\text { Terminal Space } \\
\text { Gates }\end{array}$ & $\begin{array}{l}\text { Operational } \\
\text { Costs } \\
\text { Assets }\end{array}$ & $\begin{array}{l}\text { Passengers } \\
\text { Cargo }\end{array}$ & $\begin{array}{l}\text { ATMs } \\
\text { Operational } \\
\text { Revenue }\end{array}$ & 13 \\
\hline 2 & $\begin{array}{l}\text { Terminal Space } \\
\text { Gates }\end{array}$ & $\begin{array}{l}\text { Operational } \\
\text { Costs }\end{array}$ & $\begin{array}{l}\text { Passengers } \\
\text { Cargo }\end{array}$ & $\begin{array}{l}\text { ATMs } \\
\text { Operational } \\
\text { Revenue }\end{array}$ & 15 \\
\hline 3 & $\begin{array}{l}\text { Unit Costs } \\
\text { Space/Passenger }\end{array}$ & Gates/ATM & $\begin{array}{l}\text { Passengers } \\
\text { Cargo } \\
\text { ATMs/Runway }\end{array}$ & $\begin{array}{l}\text { Unit Revenue } \\
\text { Revenue/ } \\
\text { Assets }\end{array}$ & 13 \\
\hline
\end{tabular}

Table 7: Project models

\begin{tabular}{cllc}
\hline Model & Inputs & Outputs - \% change in: & DEA Multiple \\
\hline 1 & $\%$ Change in gates, space & WLU; ATM; REVEX & 5.2 \\
\hline 2 & $\begin{array}{l}\text { Cost per unit floor space } \\
\text { Cost per gate equivalent }\end{array}$ & WLU; ATM; REVEX & 5.2 \\
\hline
\end{tabular}

\section{ANALYSIS \& DISCUSSION}

\section{General Models}

The three general models for the 107 airport years produced three sets of results, as shown in Table 8. All models produced similar average efficiency, standard deviation, similar composition, efficient set size, and the range of results. Further similarity across the models is found in Table 9, where detailed results are outlined including returns to scale (RTS) and peer counts (PC) for the efficient airports. RTS values are increasing, constant, or decreasing returns to scale - IRS, CRS, and DRS respectively. Note that the DMUs are denoted by the airport code and the data year.

Table 8: General model summary of results

\begin{tabular}{lccc}
\hline Efficiency & General Model 1 & General Model 2 & General Model 3 \\
\hline Average & 0.912 & 0.883 & 0.877 \\
Standard Dev & 0.108 & 0.128 & 0.140 \\
\# Efficient & 46 & 37 & 37 \\
\# Inefficient & 61 & 70 & 70 \\
$\%$ Efficient & $43.0 \%$ & $34.6 \%$ & $34.6 \%$ \\
Maximum & $100 \%$ & $100 \%$ & $100 \%$ \\
Minimum & $64.4 \%$ & $52.1 \%$ & $43.6 \%$ \\
\hline
\end{tabular}

Table 9: Efficiency set comparison

\begin{tabular}{ccccccccc}
\hline \multicolumn{2}{c}{ General Model 1 } & \multicolumn{2}{c}{ General Model 2 } & \multicolumn{2}{c}{ General Model 3 } \\
DMU & RTS & PC & DMU & RTS & PC & DMU & RTS & PC \\
\hline ATL90 & CRS & 7 & ATL90 & CRS & 9 & ATL90 & CRS & 0 \\
ATL94 & CRS & 2 & ATL94 & CRS & 2 & ATL94 & CRS & 2
\end{tabular}




\begin{tabular}{|c|c|c|c|c|c|c|c|c|}
\hline \multicolumn{3}{|c|}{ General Model 1} & \multicolumn{3}{|c|}{ General Model 2} & \multicolumn{3}{|c|}{ General Model 3} \\
\hline $\mathrm{DMU}$ & RTS & $\mathrm{PC}$ & DMU & RTS & $\mathrm{PC}$ & DMU & RTS & $\mathrm{PC}$ \\
\hline ATL95 & CRS & 7 & ATL95 & CRS & 5 & ATL95 & CRS & 7 \\
\hline ATL96 & DRS & 0 & ATL96 & DRS & 0 & ATL96 & DRS & 0 \\
\hline CLE97 & DRS & 3 & $\mathrm{CMH93}$ & CRS & 3 & $\mathrm{CMH93}$ & CRS & 12 \\
\hline СMH93 & CRS & 3 & СMH94 & IRS & 1 & СМH97 & CRS & 19 \\
\hline СMH94 & IRS & 0 & СMH97 & CRS & 11 & LAS95 & CRS & 31 \\
\hline СMH97 & CRS & 11 & CVG90 & CRS & 0 & LAS96 & CRS & 0 \\
\hline CVG90 & CRS & 0 & CVG91 & CRS & 0 & LASO0 & CRS & 4 \\
\hline CVG91 & CRS & 0 & LAS95 & CRS & 27 & MCO98 & DRS & 4 \\
\hline LAS95 & CRS & 21 & LAS96 & DRS & 1 & MEM99 & IRS & 0 \\
\hline LAS96 & DRS & 1 & LASO0 & DRS & 4 & MEMOO & CRS & 10 \\
\hline LAS00 & DRS & 4 & MEM99 & CRS & 0 & MEM02 & CRS & 26 \\
\hline MCO97 & DRS & 4 & MEMOO & CRS & 3 & MSP98 & DRS & 1 \\
\hline MEM99 & CRS & 2 & MEM02 & CRS & 26 & MSP01 & DRS & 1 \\
\hline MEMOO & CRS & 1 & MSP97 & DRS & 1 & PDX96 & CRS & 23 \\
\hline MEM01 & CRS & 3 & MSP98 & DRS & 0 & PDX00 & DRS & 1 \\
\hline MEM02 & CRS & 9 & PDX96 & CRS & 13 & PHL94 & DRS & 3 \\
\hline MSP97 & DRS & 1 & PDX00 & DRS & 0 & PHL98 & CRS & 0 \\
\hline MSP98 & DRS & 0 & PHL94 & DRS & 3 & PHLOO & CRS & 3 \\
\hline PDX96 & CRS & 32 & PHLO0 & DRS & 16 & PHL01 & CRS & 6 \\
\hline PDX00 & DRS & 1 & PHL01 & DRS & 5 & SEA90 & DRS & 1 \\
\hline PHL94 & DRS & 10 & SFM96 & CRS & 3 & SEA93 & DRS & 2 \\
\hline PHL95 & DRS & 0 & SFM97 & CRS & 34 & SEA94 & DRS & 2 \\
\hline PHL98 & DRS & 3 & SFO96 & CRS & 5 & SFM96 & CRS & 4 \\
\hline PHLO0 & DRS & 5 & SFO00 & CRS & 16 & SFM97 & CRS & 24 \\
\hline PHL01 & DRS & 3 & SFO01 & CRS & 11 & SFM00 & DRS & 2 \\
\hline SFM96 & CRS & 19 & SLC91 & IRS & 1 & SF096 & CRS & 4 \\
\hline SFM97 & CRS & 13 & SLC92 & CRS & 3 & SFO00 & DRS & 8 \\
\hline SFO95 & CRS & 5 & SLC94 & CRS & 52 & SFO01 & DRS & 6 \\
\hline SFO96 & CRS & 3 & SLC96 & DRS & 2 & SLC94 & CRS & 36 \\
\hline SFO00 & CRS & 10 & SLC97 & DRS & 0 & SLC96 & IRS & 1 \\
\hline SFO01 & CRS & 3 & TPA93 & CRS & 13 & TPA93 & CRS & 18 \\
\hline SLC91 & IRS & 0 & YEG98 & IRS & 2 & TPA96 & DRS & 12 \\
\hline SLC92 & CRS & 4 & YEG99 & IRS & 0 & YVR92 & CRS & 21 \\
\hline SLC93 & CRS & 4 & YVR92 & IRS & 0 & YVR93 & CRS & 15 \\
\hline SLC94 & CRS & 33 & YVR93 & DRS & 3 & YVR98 & CRS & 23 \\
\hline SLC96 & DRS & 1 & & & & & & \\
\hline SLC97 & DRS & 1 & & & & & & \\
\hline TPA93 & CRS & 8 & & & & & & \\
\hline YEG98 & IRS & 3 & & & & & & \\
\hline YEG99 & IRS & 0 & & & & & & \\
\hline YVR92 & CRS & 8 & & & & & & \\
\hline YVR93 & CRS & 9 & & & & & & \\
\hline YVR98 & CRS & 6 & & & & & & \\
\hline YYZ98 & CRS & 13 & & & & & & \\
\hline
\end{tabular}

Airports that appeared efficient across all three models were ATL, CMH, LAS, MEM, MSP, PDX, PHL, SFM, SFO, SLC, TPA and YVR. The DMUs with a peer count higher than 10 were examined; most are 
CRS and are from the pre-construction years, years 1 and 2. Of all airport-years included, there is a dominance of SLC94 ( $\left.\sum \mathrm{PC}=121\right)$ followed by LAS95 ( $\left.\sum \mathrm{PC}=79\right)$, SFM97 ( $\left.\sum \mathrm{PC}=71\right)$, PDX96 $\left(\sum \mathrm{PC}=68\right)$, and MEM02 $\left(\sum P C=61\right)$ across all model results. The next lowest peer count airport is $\mathrm{CMH} 97\left(\sum \mathrm{PC}=41\right)$.

The RTS results are of particular interest as the literature has often concluded that most airports operate at increasing returns to scale (Gillen and Lall 1997; Pels et al. 2001). Our results showed a domination of both DRS and CRS and an overall under representation of IRS. From Table 9, one can see that at least half of the efficient DMUs are CRS, suggesting that these airports were operating at their most productive size. Further examination suggests that larger locations and post-construction airport-years exhibit DRS, while smaller locations exhibit IRS. Observation also showed that CRS is more likely with years prior to construction, regardless of the size of operation. This suggests that perhaps most airports are operating unproductively with their new capacity even 2 years after completion. This is also seen by the gradual appearance of project years 4 and 5 in the efficient sets. All airports experienced a drop in efficiency over the period of the project but were starting to recover within 2 years after completion.

To further examine influences on model results, analysis of variance (ANOVA) and Chi-square tests were conducted. ANOVA identified influences of calendar year (to represent US economic periods), project year, airport size (WLU), and RTS on efficiency scores, and influences between RTS and airport size (WLU). The Chi-squared test revealed biases on the efficiency scores. The Chi-squared results followed observations of results and the ANOVA in presenting a disproportional representation of project years and RTS in the efficiency sets. The Chi-squared tests did however show an even representation of airport sizes and calendar years in the efficient set (except for size in General Model 3) while the ANOVA suggested an influence of size and economic periods on efficiency scores. Overall these results reinforced the observation that the highly peered efficient DMUs were pre-construction years and CRS.

\section{Changes in Efficiency}

The change in efficiency for each airport project was determined by subtracting the general efficiency score of the earliest year (year 1 or 2) from the latest year (year 4 or 5) for each of the three models and averaging the results, as shown in Table 10. The average change across the group was a drop in efficiency of $5.6 \%$.

Table 10: Ranked average change in efficiency

\begin{tabular}{ccc}
\hline Rank & Project & Change \\
\hline 1 & CLE & $17.6 \%$ \\
2 & SEA & $7.6 \%$ \\
3 & BWI2 & $3.3 \%$ \\
4 & BWI3 & $3.2 \%$ \\
5 & SLC2 & $1.0 \%$ \\
6 & SLC1 & $0.9 \%$ \\
7 & SLC3 & $0.9 \%$ \\
8 & ATL & $0.0 \%$ \\
9 & CMH & $0.0 \%$ \\
10 & LAS & $0.0 \%$ \\
11 & MEM & $0.0 \%$ \\
12 & PDX & $0.0 \%$ \\
13 & PHL1 & $0.0 \%$ \\
14 & YVR & $-0.1 \%$ \\
15 & MCO & $-2.8 \%$ \\
16 & BWI1 & $-4.1 \%$ \\
17 & SFM & $-5.3 \%$
\end{tabular}




\begin{tabular}{lcc}
18 & TPA & $-6.2 \%$ \\
19 & YEG & $-6.7 \%$ \\
20 & FLL & $-9.5 \%$ \\
21 & PHL2 & $-14.5 \%$ \\
22 & SFO & $-19.2 \%$ \\
23 & MSP & $-19.5 \%$ \\
24 & YYC & $-21.6 \%$ \\
25 & MSY & $-27.2 \%$ \\
26 & CVG & $-42.0 \%$ \\
& Average & $-5.6 \%$ \\
\hline
\end{tabular}

ATL, CMH, LAS, MEM, PDX, PHL1, had no net change in efficiency; however, examination of the results showed that these locations in fact did drop in efficiency, but regained their efficient status within two years of project completion. Seven locations increased performance after completion of construction, but clearly, most locations experienced a net drop in efficiency.

\section{Project Models}

Both project models were run but did not produce the similarity found across the three general models. Project Models 1 and 2 were run twice to accommodate for a discrepancy with gate counts, where either the change in gate count was the gates built by the project, or the net change in gates over the period in question (often changes due to other projects or management). However, the results were virtually identical. Therefore, change in total gate equivalents built by the project was arbitrarily used. The results are shown in Table 11.

The results of Project Model 1 and Project Model 2 show an average of project efficiency of $58.1 \%$ and $65.9 \%$ respectively. Similar to the general model results, most projects are DRS, with the remainder a mix of CRS and DRS. Airport projects from CVG, MEM, PHL1, SEA and SLC1 were efficient in both models i.e. as measured by both physical inputs of the project and the financial inputs or costs. YVR, YYC and MSY were only efficient in Project Model 2.

Table 11: Project model results

\begin{tabular}{|l|l|l|l|l|l|l|}
\hline & \multicolumn{3}{|c|}{ Project Model 1 } & \multicolumn{3}{c|}{ Project Model 2 } \\
\hline DMU & Eff & RTS & PC & Eff & RTS & PC \\
\hline ATL & 1 & DRS & 2 & 0.9 & DRS & \\
\hline BWI1 & 0.921 & DRS & & 0.697 & DRS & \\
\hline BWI2 & 1 & DRS & 5 & 0.556 & DRS & \\
\hline BWI3 & 0.528 & DRS & & 0.639 & DRS & \\
\hline CLE & 0.502 & DRS & & 0.406 & DRS & \\
\hline CMH & 0.476 & DRS & & 0.988 & DRS & \\
\hline CVG & 1 & DRS & 1 & 1 & DRS & 0 \\
\hline FLL & 0.331 & DRS & & 0.483 & DRS & \\
\hline LAS & 0.226 & DRS & & 0.255 & DRS & \\
\hline MCO & 0.742 & IRS & & 0.271 & IRS & \\
\hline MEM & 1 & CRS & 15 & 1 & DRS & 10 \\
\hline MSP & 0.171 & DRS & & 1 & DRS & 2 \\
\hline MSY & 0.429 & DRS & & 1 & CRS & 11 \\
\hline PDX & 0.353 & IRS & & 0.287 & IRS & \\
\hline PHL1 & 1 & CRS & 16 & 1 & CRS & 0 \\
\hline PHL2 & 0.342 & IRS & & 0.592 & DRS & \\
\hline SEA & 1 & DRS & 12 & 1 & DRS & 3 \\
\hline SFM & 0.032 & DRS & & 0.491 & IRS & \\
\hline SFO & 0.174 & DRS & & 0.398 & DRS & \\
\hline SLC1 & 1 & CRS & 8 & 1 & CRS & 9 \\
\hline SLC2 & 0.272 & DRS & & 0.243 & DRS & \\
\hline SLC3 & 0.567 & DRS & & 0.453 & DRS & \\
\hline TPA & 0.334 & DRS & & 0.377 & DRS & \\
\hline
\end{tabular}




\begin{tabular}{|l|l|l|l|l|l|l|}
\hline YEG & 0.509 & IRS & & 0.11 & DRS & \\
\hline YVR & 0.695 & DRS & & 1 & DRS & 3 \\
\hline YYC & 0.512 & DRS & & 1 & DRS & 6 \\
\hline Mean & 0.581 & & 2.27 & 0.659 & & 1.69 \\
\hline
\end{tabular}

Project Efficiency and Changes in Efficiency

Table 12 was developed to examine the relationship between project efficiency and the changes in efficiency over time. The bolded projects are those that occur in both lists within 5 rank places. (Note that the criterion of 5 was arbitrary.) Six of the ten occurrences are in the lower half of the table where changes over time were negative. By inspection, there does not appear to be a relationship between the two results, and correlation analysis provided a weak relationship rho=-0.06. Based on these results, there is no evidence to support a claim that project efficiency (as defined here) and its impact on the overall airport's efficiency are related.

Table 12: Ranking projects

\begin{tabular}{|c|c|c|c|c|c|}
\hline \multicolumn{3}{|c|}{ Average Change in Efficiency } & \multicolumn{3}{|c|}{ Average Project Efficiency } \\
\hline Rank & Project & Change & Rank & Project & Efficiency \\
\hline 1 & CLE & $17.6 \%$ & 1 & CVG & $100.0 \%$ \\
\hline 2 & SEA & $7.6 \%$ & 2 & MEM & $100.0 \%$ \\
\hline 3 & BWI2 & $3.3 \%$ & 3 & PHL1 & $100.0 \%$ \\
\hline 4 & BWI3 & $3.2 \%$ & 4 & SEA & $100.0 \%$ \\
\hline 5 & SLC2 & $1.0 \%$ & 5 & SLC1 & $100.0 \%$ \\
\hline 6 & SLC1 & $0.9 \%$ & 6 & ATL & $95.0 \%$ \\
\hline 7 & SLC3 & $0.9 \%$ & 7 & BWI1 & $80.9 \%$ \\
\hline 8 & ATL & $0.0 \%$ & 8 & YVR & $77.9 \%$ \\
\hline 9 & CMH & $0.0 \%$ & 9 & BWI2 & $77.8 \%$ \\
\hline 10 & LAS & $0.0 \%$ & 10 & YYC & $75.6 \%$ \\
\hline 11 & MEM & $0.0 \%$ & 11 & $\mathrm{CMH}$ & $72.9 \%$ \\
\hline 12 & PDX & $0.0 \%$ & 12 & MSY & $71.5 \%$ \\
\hline 13 & PHL1 & $0.0 \%$ & 13 & MSP & $58.6 \%$ \\
\hline 14 & YVR & $-0.1 \%$ & 14 & BWI3 & $58.4 \%$ \\
\hline 15 & MCO & $-2.8 \%$ & 15 & SLC3 & $51.0 \%$ \\
\hline 16 & BWI1 & $-4.1 \%$ & 16 & MCO & $50.7 \%$ \\
\hline 17 & SFM & $-5.3 \%$ & 17 & PHL2 & $46.7 \%$ \\
\hline 18 & TPA & $-6.2 \%$ & 18 & CLE & $45.4 \%$ \\
\hline 19 & YEG & $-6.7 \%$ & 19 & FLL & $40.7 \%$ \\
\hline 20 & FLL & $-9.5 \%$ & 20 & TPA & $35.6 \%$ \\
\hline 21 & PHL2 & $-14.5 \%$ & 21 & PDX & $32.0 \%$ \\
\hline 22 & SFO & $-19.2 \%$ & 22 & YEG & $31.2 \%$ \\
\hline 23 & MSP & $-19.5 \%$ & 23 & SFO & $29.0 \%$ \\
\hline 24 & YYC & $-21.6 \%$ & 24 & SFM & $26.3 \%$ \\
\hline 25 & MSY & $-27.2 \%$ & 25 & SLC2 & $25.8 \%$ \\
\hline \multirow[t]{2}{*}{26} & CVG & $-42.0 \%$ & 26 & LAS & $24.1 \%$ \\
\hline & Average & $-5.6 \%$ & & Average & $61.8 \%$ \\
\hline
\end{tabular}

\section{Correlation Analysis}

A number of correlation studies were undertaken as shown in Table 13 to determine if any of the variables used in the analysis either overwhelmed the DEA or could serve as an indicator of efficiency. No such obvious variables were identified. The bolded values indicate an absolute rho greater than 0.3 . 
Table 13: Correlation coefficients with model efficiencies

\begin{tabular}{|c|c|c|c|c|c|c|}
\hline \multirow[b]{2}{*}{ Factor } & \multicolumn{3}{|c|}{ General Models } & \multirow{2}{*}{$\begin{array}{c}\% \text { Factor } \\
\text { Change }\end{array}$} & \multicolumn{2}{|c|}{ Project Models } \\
\hline & $\# 1$ & \#2 & \#3 & & $\# 1$ & \#2 \\
\hline \multicolumn{7}{|l|}{ Basic Variables } \\
\hline$\overline{\text { Annual Passengers }}$ & 0.26 & 0.24 & 0.32 & -0.26 & 0.38 & 0.45 \\
\hline Cargo & 0.25 & 0.24 & 0.26 & -0.01 & 0.44 & 0.15 \\
\hline Work load units (WLU) & 0.32 & 0.30 & 0.38 & -0.23 & 0.43 & 0.45 \\
\hline Air traffic movements (ATM) & 0.33 & 0.30 & 0.40 & -0.22 & 0.36 & 0.37 \\
\hline Terminal Space & 0.14 & 0.07 & 0.12 & -0.23 & -0.28 & 0.03 \\
\hline Gates & 0.06 & 0.01 & 0.10 & -0.26 & -0.17 & 0.12 \\
\hline Runways & -0.05 & -0.00 & -0.03 & 0.23 & 0.06 & -0.01 \\
\hline Assets & 0.13 & 0.18 & 0.24 & 0.01 & -0.06 & 0.24 \\
\hline Debt & 0.16 & 0.18 & 0.20 & 0.07 & -0.16 & 0.15 \\
\hline Operating costs & 0.09 & 0.02 & 0.07 & -0.31 & 0.04 & 0.20 \\
\hline Operating revenues & 0.20 & 0.15 & 0.22 & -0.15 & -0.06 & 0.20 \\
\hline \multicolumn{7}{|l|}{ Asset Utilization } \\
\hline$\overline{\text { ATM/Runway }}$ & 0.38 & 0.30 & 0.54 & -0.40 & 0.21 & 0.25 \\
\hline Terminal space/Passenger & -0.16 & -0.27 & -0.28 & -0.09 & -0.51 & -0.27 \\
\hline Gates/ATM & -0.42 & -0.44 & -0.41 & -0.22 & -0.48 & -0.10 \\
\hline Passengers/Gate & 0.38 & 0.41 & 0.45 & 0.15 & 0.54 & 0.30 \\
\hline WLU/ATM & 0.08 & 0.10 & 0.19 & -0.12 & 0.20 & 0.30 \\
\hline Passengers/ATM & -0.03 & -0.07 & 0.09 & -0.16 & 0.13 & 0.30 \\
\hline \multicolumn{7}{|l|}{ Finances } \\
\hline 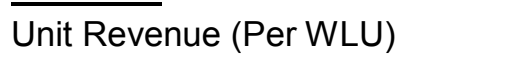 & -0.15 & -0.15 & -0.11 & 0.22 & -0.33 & -0.08 \\
\hline Unit Cost (Per WLU) & -0.26 & -0.28 & -0.37 & -0.22 & -0.31 & -0.12 \\
\hline Leverage & 0.12 & -0.08 & -0.05 & 0.29 & -0.15 & -0.19 \\
\hline \multicolumn{7}{|l|}{ Costs } \\
\hline Total costs & -0.02 & 0.06 & 0.12 & -0.02 & -0.28 & 0.01 \\
\hline$\%$ Operating costs (of Total) & -0.03 & -0.15 & -0.14 & -0.05 & 0.62 & 0.24 \\
\hline Operating costs/Terminal Space & 0.07 & 0.10 & 0.06 & -0.10 & 0.25 & 0.14 \\
\hline Operating costs/Gate & 0.06 & 0.03 & -0.01 & -0.17 & 0.15 & 0.10 \\
\hline \multicolumn{7}{|l|}{ Revenues } \\
\hline Total revenue & 0.15 & 0.18 & 0.30 & 0.06 & -0.07 & 0.21 \\
\hline$\%$ Operating revenue (of Total) & 0.08 & -0.03 & 0.15 & 0.15 & -0.01 & -0.18 \\
\hline Operating revenue/Terminal space & 0.18 & 0.24 & 0.23 & 0.49 & 0.18 & 0.16 \\
\hline Operating revenue/Gate & 0.24 & 0.23 & 0.26 & 0.39 & 0.09 & 0.11 \\
\hline \multicolumn{7}{|l|}{ Profit } \\
\hline Operating profit & 0.32 & 0.31 & 0.41 & 0.04 & 0.05 & 0.37 \\
\hline Unit Profit (per WLU) & 0.15 & 0.17 & 0.36 & -0.03 & 0.01 & 0.33 \\
\hline REVEX & 0.36 & 0.41 & 0.48 & 0.67 & 0.02 & 0.11 \\
\hline Operating ratio & -0.31 & -0.36 & -0.50 & -0.67 & 0.14 & 0.07 \\
\hline Return on assets (ROTA) & 0.23 & 0.12 & 0.19 & 0.33 & 0.09 & 0.09 \\
\hline \multicolumn{7}{|l|}{ Capital Productivity } \\
\hline Operating revenue/Assets & 0.13 & 0.01 & 0.01 & 0.41 & 0.09 & -0.19 \\
\hline WLU/Assets & 0.15 & 0.06 & 0.06 & 0.12 & 0.35 & 0.03 \\
\hline Passengers/Assets & 0.14 & 0.04 & 0.04 & 0.11 & 0.32 & 0.03 \\
\hline ATM/Assets & 0.14 & 0.05 & 0.05 & 0.25 & 0.23 & -0.05 \\
\hline Cargo/Assets & 0.23 & 0.16 & 0.17 & 0.15 & 0.38 & -0.08 \\
\hline Additional Variables & & & & & & \\
\hline
\end{tabular}




\begin{tabular}{|c|c|c|c|c|c|c|}
\hline \multirow[b]{2}{*}{ Factor } & \multicolumn{3}{|c|}{ General Models } & \multirow{2}{*}{$\begin{array}{r}\% \text { Factor } \\
\text { Change }\end{array}$} & \multicolumn{2}{|c|}{ Project Models } \\
\hline & $\# 1$ & \#2 & \#3 & & \#1 & \#2 \\
\hline Aeronautical revenue & 0.16 & 0.20 & 0.22 & -0.14 & -0.40 & -0.22 \\
\hline $\begin{array}{l}\% \text { Aeronautical revenue (of } \\
\text { Total) }\end{array}$ & 0.03 & 0.05 & -0.01 & -0.24 & -0.34 & -0.21 \\
\hline Unit aeronautical (per WLU) & -0.05 & -0.02 & -0.07 & -0.26 & -0.43 & -0.27 \\
\hline International traffic (passengers) & 0.25 & 0.13 & -0.17 & -0.29 & 0.06 & 0.28 \\
\hline$\%$ International traffic (of Total) & 0.04 & -0.04 & -0.06 & -0.04 & -0.13 & 0.05 \\
\hline Project Variables & & & & & & \\
\hline Total project cost & - & - & - & -0.36 & -0.13 & -0.13 \\
\hline Project duration & - & - & - & -0.47 & 0.05 & 0.25 \\
\hline Space built & - & - & - & -0.48 & -0.11 & 0.07 \\
\hline$\%$ Increase in space & - & - & - & -0.32 & -0.32 & 0.09 \\
\hline Gates Built & - & - & - & -0.54 & -0.11 & 0.02 \\
\hline$\%$ Increase in Gates & - & - & - & -0.23 & -0.33 & -0.15 \\
\hline Project cost/Space & - & - & - & 0.42 & 0.09 & -0.36 \\
\hline $\begin{array}{l}\text { Project cost } / \% \text { Increase in } \\
\text { space }\end{array}$ & - & - & - & 0.26 & 0.52 & 0.16 \\
\hline Project cost/Gates built & - & - & - & 0.07 & 0.03 & -0.19 \\
\hline Project cost $/ \%$ Increase in gates & - & - & - & 0.06 & 0.48 & 0.10 \\
\hline
\end{tabular}

In General Model 1, the two highest correlation coefficients were the measures of asset utilisation, where rho $=0.42$ for gates per ATM, and rho $=0.38$ for both passengers per gate and ATM/Runway. These observations support results from other studies that suggest gates are influential to the overall performance both on the airside and groundside (Gillen and Lall 1997). This also follows literature that stresses the management of gates as critical in operational control (Cooper and Gillen 1994; Gillen and Stang 1996). Yet, the basic factor of gates has low correlation with all of the models. The measure of ATM/Runway suggests a positive influence of the airside on overall operational performances.

It is interesting to note that lower correlation coefficients were found between efficiency values and passengers, cargo, WLU and ATMs than measures of asset utilization. One would expect that the operational size of an airport should be a factor in the efficiency rankings - this intuition is supported by the observation of smaller airports at the lower end of the efficiency ranks. However, if these relationships exist, they are not statistically significant to chi-squared and ANOVA evaluation.

As with General Model 1, there were few correlation coefficients of significance found with the results of General Model 2. The correlation of General Model 2 results presented its highest three coefficient value with gates per ATM at rho $=0.44$, passengers per gate at rho $=0.41$, and rho $=0.41$ with REVEX, which was highly correlated with all of the models. The stronger relationship of gates per ATM suggests again the importance of airside operations on overall operational performance and efficiency.

Overall General Model 3 showed stronger correlation coefficients than General Models 1 and 2, the highest of which were found with runways per ATM at rho $=-0.57$, operating ratio rho $=0.50$ and $r h o=0.48$ with REVEX. These differ from Models 1 and 2, but there are other trends found across all three general models. As ATMs increase (holding runway counts static), efficiency increases (rho=0.40), thus suggesting once again that airside operations add to overall airport performance. The strong relationships between efficiency and operating ratio, and efficiency and REVEX advocate the intuitive response that locations that realize returns on dollars spent should be more efficient.

What these results show is that while volume is significant in the rank of efficiency (likely due to economies of scale), perhaps the productivity of facilities may be the deciding factor on the degree to 
which performance is negatively affected by the development of passenger terminals. Operating profit had moderate correlation with efficiency, but REVEX and (its reciprocal) Operating Ratio are good indicators of return on costs despite the fact that most airports are operated as non-profit corporations. Surprisingly, measures of capital productivity had little significance.

\section{Overall Analysis}

The time series nature of the data and study allows the impact over time to be examined. The percent change in efficiency was correlated with the other variables over the same period of time. The results in Table 13 clearly show the intuitive influence of operating costs (rho=-0.31) and measures of project scale on the changes of efficiency. Positive correlation coefficients can be seen with operating revenue per terminal space $(r h o=0.49)$ and operating revenue per gate $(r h o=0.39)$. Although the direct influence of operating revenue is weak at rho $=0.15$, the measures of REVEX (rho=0.67), Operating Ratio (rho=0.67 ), ROTA (rho=0.33) and Operating Revenue per asset (rho=0.41) appear to have an influence on volume and revenue measures. Within project measures, as the scale of the project increases, the percent increase in efficiency declines. This is intuitive as the scale of operation grows, cost recovery begins while there is underutilization of the new capacity. This suggests that there is still underutilization at 2 years of operation after construction. Increased project scale causes a large drop in efficiency over time, as illustrated by project cost $(\mathrm{rho}=-0.36)$, space built (rho=-0.48), gates built (rho $=-0.54)$, project cost per unit space (rho=0.42), percent increase in space (rho=-0.32) and project duration (rho $=-0.47$ ). These results simply show that as time, costs and size of the project increase, so does the negative impact, and that as the cost per space built increases, efficiency will increase over time. This may be indicative of more specialized space being built; space perhaps that can offer services immediately after completion and can generate immediate revenues, such as commercial space. A final observation is that the influence of gates seems to be secondary to that of space.

The coefficients for Project Model 1 and 2 identify a number of strong relationships. The frequency of significant correlation with Project Model 1 clearly surpasses that with Project Model 2. The highest measures are with terminal space per passenger (rho=-0.51), passengers per gate (rho $=-0.54)$, percent operating costs $(r h o=0.62)$, and project costs per percent increase in space $(r h o=0.52)$. These results follow literature suggesting that as congestion of space and gates increases, profit and revenue will increase due to high productivity of facilities, thus increasing output, realized in REVEX and WLU, thus in turn aiding in recovery after project completion. Increases in operating costs versus total costs imply that interest costs and overhead costs reduce over time. As with cost per percent space increase, positive correlations imply the rate of recovery would increase again due to the nature of space being built to provide useful and quality space for revenue generative services.

Results of Project Model 2 showed that volume causes an increase in efficiency, but other strong relationships exists with measures of utilization and size of aircraft. The importance of aircraft size generally means more international traffic. International traffic has been known to be targeted for its ability to recover costs when construction is completed (Doganis 1992). This aligns with the previous analyses results implying an influence of airside operations on overall performance when there is a disturbance on the landside. There is also a stronger correlation to measures of unit project costs. These negative values contradict the high positive values of the costs per percent change in space and gates with Project Model 1. This may be due to the measures included in the DEA project models.

\section{CONCLUSION}

The analyses suggest that the short term impacts of redevelopment on selected indicators of airport and operations performance measures may be anticipated. The results of the project models were interesting but due to the small sample size, may be biased. However, the positive correlation coefficients of space per passenger, passenger per gate, and revenue per passenger and gate with efficiency are indicative of what needs to occur to realize return on investment - operating at full capacity. Once the space and gates are highly utilized, revenues are generated and costs are recovered. 
Observations of the other models pointed to gate management to increase productivity for both the landside and airside operations. ATM per runway was consistently positive to efficiencies and changes in efficiency, as with the other variables tied to airside operations (cargo measures, ATMs etc).

The relevance of the REVEX measure came to light as it consistently appeared as an indicator of positive effects on efficiency. This observation is well received as it has been supported in literature as the best alternative to measures of profit or revenues for regulated or non-profit organizations. This measure indicated a stronger relation to efficiency than size in the context to regaining efficiency once the project is completed. What was of interest is that not only the scale of the project is important but also what is being built, suggesting that space has a close relationship to changes in efficiencies over time, as shown by project costs per unit space. As found in the literature, it is believed that the strategic use of space is critical to operational efficiency via revenues and perhaps the full range of nonaeronautical services that can be offered at airports. Higher cost facilities tend to support revenue earning retails services that, once built, contribute to financial recovery and can increase overall utilization. These facilities are relevant as they may offer services targeted to international traffic, which is helpful for financial recovery.

Overall results pointed to various groups of airports and projects that were successful by yearly operations, over time, or by projects. Operational years that came out successful include SLC94, PXD96, LAS95, SFM97 and CMH97. These represent a mix of airports in size and traffic. ATL, CMH, LAS, MEM, PDX, and SLC1 found high ranking in the analyses for a zero net change in efficiency. These locations had numerous efficient years, dipped in efficiency, but then recovered within the two year post construction operational period. CLE, SEA and BWI produced increases in efficiency over time, although these locations did not show positive results in the other analyses. Also noted was the lack of smaller Canadian airports in the top ranks of the various analyses. This must be further investigated, but may be due to their lower volume of traffic and their costs/revenue structure.

\section{ACKNOWLEDGEMENTS}

The authors gratefully acknowledge the financial of IOR Grant \#216754-98 from the Greater Toronto Airports Authority and NSERC, and research support from MGP Project Managers and all of the airport authorities that provided their data for this research.

\section{REFERENCES}

ACl.1998. World Wide Airport Traffic Report - 1997, Airports Council International, Geneva, Switzerland.

ACI. 2003. Annual 2002 World Traffic Report. Available from http://www.airports.org [cited 23 October, 2003].

Adler, N. and Berechman, J. 2001 Measuring airport quality from the airlines' viewpoint: an application of data envelopment analysis. Transport Policy, 8: 171-181

ATRS.2002. Airport Benchmarking Report 2002: global standards for airport excellence. Air Transport Research Society, Vancouver, BC, Canada.

Banker, R.D., 1984. Estimating most productive scale size using data envelopment analysis. European Journal of Operational Research, 17: 35-44.

Banker, R.D., Charnes, A., and Cooper, W.W. 1984. Some models for estimating technical and scale inefficiencies in data envelopment analysis. Management Science, 30: 1078-1092

Bazargan, M., and Vasigh, B. 2003. Size versus efficiency: a case study of US commercial airports, Journal of Air Transport Management, 9: 187-193.

Boussofiane, A., Dyson, R.G., and Thanassoulis, E. 1991. Applied data envelopment analysis, European Journal of Operational Research, 52: 1-15. 
Charnes, A., Cooper, W.W., and Rhodes, E.L. 1978. Measuring the efficiency of decision making units, Journal of Operations Research, 2: 429-444.

Cooper, D. and Gillen, D. 1994. Measuring Airport Efficiency and Effectiveness in the California Aviation System. Institute of Transportation Studies, University of California at Berkley, CA, United States.

de Neufville, R. and Rojas Guzmán, J. 1998. Benchmarking of design for major airports worldwide, Journal of Transportation Engineering, 124: 391-395.

Doganis, R. 1992. The Airport Business. Routledge, Chapman and Hall Inc. New York, New York, United States.

Doganis, R., and Graham, A. 1987. Airport management: the role of performance indicators. Transport Studies Group, Polytechnic of Central London, UK.

FAA. CATS (Compliance Activity Tracking System) Database [online]. Available from http://cats.crownci.com [cited March - September 2003]

Fernandes, E. and Pacheco, R.R. 2002. Efficient use of airport capacity, Transportation Research Part A, 36: 225-238

Francis, G., Humphreys, I., and Fry, J. 2002. The benchmarking of airport performance, Journal of Air Transport Management, 8: 239-247.

Gillen, D and Lall, A. 1997. Developing measures of airport productivity and performance: an application of Data Envelopment Analysis. Transportation Research Part E: Logistics and transportation review. 33: 261-273.

Gillen, D and Stang, D.J. 1996. Performance Measurements: The Keystone in Benchmarking and Total Quality Management: A Performance Measurement System for Pearson International Airport. Prepared for Greater Toronto Airports Authority, Toronto.

Graham, A. 2001. Managing Airports: an international perspective. Butterworth Heinemann, Boston, Massachusetts, US.

Graham, A. 2003. Benchmarking and measuring performance in the airport industry. Airport Economic and Finance Symposium, 2003, Cranfield University/University of Westminster, UK.

Hooper, P.G. and Hensher, D.A. 1997. Measuring total factor productivity of airports an index number approach, Transportation Research Part E: Logistics and transportation review, 33: 249-259.

Humphreys, I. and Francis, G. 2000. Traditional airport performance indicators: a critical perspective, Transportation Research Record 1703, 24-30.

Martín, J.C. and Román, C. 2001. An application of DEA to measure the efficiency of Spanish airports prior to privatization, Journal of Air Transport Management, 7: 149-157.

Mackenzie-Williams, Peter. 1997. Time to measure up. (airport industry must accept performance indicators). Airline Business, 13, 9: 98-100.

NERA. 2001. The Application of Benchmarking to Airports Phase 1: Data Collections and Assessment: A Final Report for the Civil Aviation Authority. London, UK.

Pels, E, Nijkamp, P and Rietveld, P. 2001. Relative efficiency of European airports. Transport Policy, 8: 183-192.

Sarkis J. 2000. An analysis of the operational efficiency of major airports in the United States, Journal of Operations Management, 18: 335-351.

\section{ABBREVIATIONS}

ANOVA analysis of variance

ATL Hartsfield Atlanta International

ATM air traffic movements

BCC Banker, Charnes and Cooper model (variable returns to scale)

BWI Baltimore/ Washington International

CATS FAA's compliance activity tracking system

CCR Charnes, Cooper and Rhodes model (constant returns to scale)

CLE Cleveland Hopkins International 
$\mathrm{CMH}$ Port Columbus International

CRS constant returns to scale

CVG Cincinnati/Northern Kentucky International

DEA data envelopment analysis

DMU decision making unit

DRS decreasing returns to scale

FAA Federal Aviation Authority

FLL Fort Lauderdale/ Hollywood International

IRS increasing returns to scale

LAS McCarran International, Las Vegas

MCO Orlando International

MEM Memphis International

MSP Minneapolis/ St.Paul International

MSY New Orleans International

PC peer counts

PDX Portland International

$\mathrm{PHL}$ Philadelphia International

REVEX revenue to expenditure ratio

RTS returns to scale

SEA Seattle Tacoma International

SFM Sacramento International

SFO San Francisco International

SLC Salt Lake City International

TFP total factor productivity

TPA Tampa International

VRS variable returns to scale

WLU work load unit

YEG Edmonton International

YVR Vancouver International

YYC Calgary International

YYZ Toronto Pearson International 